\title{
A DYNAMiC MACROECONOMiC MOdEL OF THE NigERIAN ECONOMY WITH EMPHASIS ON THE MONETARY SECTOR
}

\author{
Enang Bassey Udah
}

Department of Economics, University of Calabar-Nigeria

\begin{abstract}
The dynamic nexus between money supply, fiscal deficit, inflation, output and exchange rate management has recently generated much debate in economic literature in Nigeria. To contribute to this debate, this paper uses the co-integration and error correction framework of analysis and also conducts policy simulation experiments to investigate how monetary variables interact with aggregate supply, demand and prices in order to aid stabilisation policies. The results show that monetary variables and government finance are linked through government's net indebtedness to the banking system. The simulation results show that a 20 per cent monetary squeeze would reduce the inflation rate faster than if the reduction in money supply were 10 per cent. This reduction in money supply would also lead to a reduction in output, employment and government expenditure, which may hurt the domestic economy. The paper thus concludes that there is a trade-off between higher GDP growth and inflation in Nigeria.
\end{abstract}

Key words: monetary policy, fiscal policy, macroeconomic management, simulation experiment

JEL E52, E62

\section{1 \\ Introduction}

The poverty of knowledge on the part of policy-makers as far as the precise quantitative relation among variables in the monetary and fiscal sectors is concerned has often been offered as the major cause of distortions in key macroeconomic aggregates. In Nigeria, the interaction between the monetary sector and the fiscal sector is of great importance. This is because a substantial portion of the fiscal deficit is financed by the Central Bank of Nigeria's (CBN) credit to government. Tobin (1999: 4) maintains that monetary and fiscal policies are distinct only in financially developed countries, whose governments do not have to finance budget deficits through seigniorage. In such advanced economies, a government can sell obligations to pay money in the future, like the US Treasury bills, notes, and bonds. Nigeria, however, is different, because, over the years, the growth rate of the money supply (M2) has been closely linked to the monetisation of budget deficit, which makes the growth rate of M2, GDP and inflation very volatile. For instance, the growth rate of M2 was 8 per cent in 1971 , increasing to 15.81 per cent in 1975 . By 1980, it was 32.98 per cent; it dropped to 23.42 per cent in 1990 and increased marginally to 48.1 per cent in 2000, before dropping to 24.1 per cent in 2003. In 2004 it dropped further to 14 per cent. The gross domestic product (GDP) growth rate, which was 21.35 per cent in 1971, fell to -2.96 in 1975 , while the inflation rate increased remarkably from 15.8 per cent in 1971 to 33.9 per cent in 1975. The balance of payments and the exchange rate remained relatively stable from 1970 to 1975 . However, from 1979 the economy began to show signs of a depression that by 1983 was well advanced. Between 1980 and 1988, the gross domestic product grew at a negative rate, while the inflation and unemployment rates rose to a very high level. Disequilibrium in the balance of payments exacerbated the external debt crisis. 
The recession, which had been affecting the Nigerian economy since mid-1981, continued through 1983. GDP, which had fallen by 0.34 per cent in 1982, declined by a further 5.37 per cent in 1983, but recorded a moderate increase of 3.13 per cent in 1986 . The broad money supply followed a similar pattern, as shown in Table 1.1. From 1992 to 2002, the economy passed through another period of serious macroeconomic instability characterised by large deviations of macroeconomic aggregates from policy targets. For instance, the 2002 policy target was a GDP growth rate of 5 per cent, but was, in fact, 3.5 per cent. In the same year, the target for M2 was 15.3 per cent, but at the end of the year it was 26 per cent. The inflation rate follows a similar pattern, deviating from a policy target of 9.3 per cent to 12.9 per cent. Apart from a few exceptions, this has been the trend in other key macroeconomic aggregates. There were also increased pressures in the domestic and external sectors of the economy and marginal decline in the performance of the real sector. However, the economy performed substantially better in 2003 . Available statistics from the National Bureau of Statistics (NBS) show that the GDP increased by 10.2 per cent, as compared with 3.5 per cent in 2002. Inflationary pressure persisted; inflation rose to 14 per cent in 2003 from 3.5 per cent in 2002 (CBN annual report and statements of account on various issues). The major source of macroeconomic instability has often been attributed to the increasing magnitude of the money supply, which exerts pressure on the exchange rate and domestic demand and hence on prices.

In addition, Figures 1.1 and 1.2 show that both the output growth rate and the inflation rate manifested considerable variation from year to year. In 2000, for instance, the GDP increased by 3.8 per cent as compared with 2.8 per cent in 1999. Inter alia, the monetisation of crude oil proceeds contributed to the observed GDP growth. Inflation, as measured by the composite consumer price index, fluctuated considerably during this period. The upward movement in prices is attributed to the excess liquidity in the banking system arising from, once again, the monetisation of enhanced crude oil export receipts.
This observed instability in key macroeconomic variables calls into question whether policymakers precisely understand the quantitative relationship between variables in the monetary and the real sectors, and how monetary stimulus affects various sub-sectors of the economy.

The major aim of this paper is to investigate, using a macroeconomic model, how monetary variables affect various sub-sectors of the Nigerian economy. The specific objectives are to investigate the response by key endogenous variables to policy shocks and to articulate policies to promote economic growth with monetary stability. The study will be significant in assisting policy-makers to gain useful insights into how monetary policy variables affect the various sub-sectors of the Nigerian economy. Such an understanding, in the researchers' opinion, will help the Central Bank of Nigeria to formulate and implement useful monetary policy from sets of economic choices and to better appreciate the inter-connections within the economy.

Following the introduction, the rest of the paper is organised into four sections. Section two presents the theoretical underpinnings of the study and reviews related literature. In section three, the researchers develop the methodological framework of the study. Empirical results and discussions are presented in section four. In section five the researchers make some useful recommendations and concluding comments.

\section{2}

\section{Theoretical framework and literature review}

\subsection{Theoretical framework}

In formulating the theoretical basis of this work, the researchers follow an eclectic approach. In other words, they derive theoretical ideas from different theoretical paradigms, the main motivators being the supply and demand arguments of the monetarist, classical, Keynesian and neoclassical schools.

Monetarism has several essential features. First, it is the reincarnation of classical macroeconomics, with its focus on the long-term 
properties of the economy, including the neutrality of money and the quantity theory of money. Neutrality holds if the equilibrium value of real variables, including the level of output, is independent of the level of the money supply in the long run. The quantity theory of money argues that prices move proportionately to link money growth. Together, these propositions identify what monetary policy can and cannot achieve, and they therefore delineate the responsibilities of central banks.

Second, monetarism focuses less on the structure of the economy and the short-run dynamics than on long-run conclusions, such as the relationship between money and output, and money and inflation. For this reason, monetarists tend to prefer reduced form equations to structural equations or structural econometric models and to focus more on longrun results rather than short-run dynamics. This focus reflects, in part, the researchers' scepticism about the use of monetary policy to understand or to adequately quantify the structural linkages and dynamics in the economy. For this reason, they incorporate aspects of Keynesian theorising, which focuses on short-run dynamics.

Third, monetarists are sceptical of the use of monetary policy for short-run stabilisation, despite the fact that they believe short-run variations in money growth do affect aggregate demand and hence output. As a result, they favour often-passive rules that focus on achieving a rate of money growth that is consistent with long-term price stability, with no adjustment to cushion short-run fluctuations in aggregate demand. This preference reflects again the uncertainty about the structure of the economy, about short-run dynamics, and the long and variable lags in the response of aggregate demand to changes in the money supply.

Meyer (2001: 106-110) maintains that the monetarists' model contains three innovations, which seek to improve the IS-LM framework without entirely discarding it. First, the IS-LM model has two equations and three unknowns and therefore could be solved only by assuming that either the price level or the output level is fixed. The monetarists' model allows for both sticky prices in the short run and full price flexibility in the long run by introducing the Phillips curve. In effect, the curve pins down the degree to which prices are sticky in the short run, allowing scope for both short-run movements in actual output relative to potential, and for stabilisation policy, while providing a mechanism that ensures smooth transition to the classical equilibrium in the long run.

Second, the monetarists' new model replaces the LM equation with a policy rule. The LM curve expresses the equilibrium condition in the money market, the balance between the supply of and the demand for money. Implicitly, the money supply is treated as the instrument of monetary policy. The policy rule in the monetarists' new model specifies the way in which policy-makers adjust the interest rate to economic developments. This specification has the advantage of more accurately capturing the prevailing operation procedure at central banks around the world, given that, almost without exception, they implement monetary policy by setting a target for some key interest rate. This also reflects a more modern view of "policy" as a systematic adjustment of the policy instrument to ongoing economic development rather than simply being an exogenous process outside the model.

Third, the model explicitly incorporates forward-looking elements into economic behaviour and accounts for the importance of expectation. In the eclectic form used in this paper, the model allows for both forwardlooking elements and lagged adjustment due, for example, to the adjustment costs.

The neoclassical theory focuses more on the supply of goods and services in an economy. It identifies capital accumulation or investment and labour employment as well as technological progress as the dominant factors promoting economic growth. The theory argues that, to achieve sustained economic growth and development, a country should tackle the problem from the supply perspective. This includes the provision of infrastructure such as power, safe drinking water, communication facilities and roads, as well as policies that will boost export growth (Jhingan, 1997; Ndebbio \& Ekpo, 1991). 


\subsection{Literature review}

The history of macro-econometric modelling is of interest. It was initially developed to implement Keynes' General theory. Later, other alternative, paradigms, such as monetarist, New Keynesian and New Classical, have been incorporated into macro-econometric models (MEMs) (Bodkin, Klein \& Marwah, 1986b: 439; Valadkhani, 2003).

Palanivel and Klein (1999: 277-230) constructed an MEM for India to show the dynamic nexus between fiscal deficit, money supply, inflation and output. Individual case studies for Nigeria include those by Ojo (1973), Olofin and Poloamina (1984), Uwujaren (1977), Iyoha (2002), Soludo (1998) and Ikhide (1998). With the exception of Ikhide (1998), the other Nigerian case studies were essentially planning models and their specification of the financial sector was rudimentary. Ikhide (1998: 6-12) simulated a well-specified financial sector of the Nigerian economy. However, his study made no attempt to integrate the financial sector with the other sectors of the Nigerian economy. The integration of the financial sector with real variables such as, inter alia, GDP, consumption or investment, lends itself to extensive policy analysis. Bogunjoko (1997: 144) used the co-integration paradigm to show that monetary policy largely defines the direction of the Nigerian economy. The study ignored the importance of simulation analysis in response to policy shocks.

This paper is an extension of Ikhide's study (1998), in which he simulated only the financial sector of the Nigerian economy, ignoring sectors such as the real sector or the external sector. Ignoring these other sectors meant that policy analysis could not be undertaken, because the model of the financial sector alone does not allow flexibility in policy analysis. It would have to be combined with other sectors where policy analysis could be performed on major macroeconomic variables like GDP, investment, money supply or consumption. This study is intended to address this lacuna.

\section{Methodological framework}

\subsection{The model}

The macro-econometric model(MEM) proposed in this study is ideal, because it provides information on the dynamics of the adjustment process. This in turn is useful for short-term and medium-term forecasting and policy analysis. It is also structural in the sense that it allows the formal use of econometrics as the best tool for policy analysis at the macro level. It stresses the crucial role played by monetary variables in the behaviour of key macroeconomic aggregates like inflation, output and balance of payments. The analysis can therefore be considered a generalisation of the models developed in the context of the monetary approach to balance of payments. Even though monetary factors are assigned a dominant role, the study assumes that, within the Nigerian context, money supply is not necessarily under the close control of the Central Bank of Nigeria, the capital market is not well developed, and therefore the credit growth rate may be closely linked to the government's borrowing requirements and hence to its fiscal policy. In this model, monetary (cum fiscal) policy is the relevant means by which policy-makers seek to achieve their objectives, and it is the domestic component of the money stock that is the instrument of policy. The macroeconomic model used in this study is of medium size. This is because the number of equations exceeds 20 but is less than 100 (Iyoha, 1996: 168). The model has 31 equations, of which 18 are of stochastic relationship and 13 are identities. The model discussed below is adapted from a well-known equation system, tractable and relevant; it benefits greatly from the works of Ojo (1973), Ajayi (1978), Khan and Knight (1981), Soludo (1998), Olofin and Poloamina (1984) and Ikhide (1998).

The model is broadly classified into six blocks: monetary, fiscal, production, aggregate demand, the labour market and the external sector block. This classification is doubly important. It allows the researchers to capture the crucial role played by monetary variables in the behaviour of macroeconomic aggregates such as inflation, 
output and balance of payments, and by the transmission mechanism of monetary policy in terms of financial market quantities and prices.

In the monetary block, the researchers specify equations that show the demand and supply of money and an inflation equation. On the demand side, they disaggregate into the demand for currency outside banks, savings deposits and time deposits. Money supply is the sum of monetary base and fiscal deficit. They close the monetary block with an identity showing equilibrium in the money market.

Output in the production block is divided into oil and non-oil. The non-oil sector is disaggregated into agriculture and manufacturing. The output of the agriculture sector is aggregative and relates to credit to the agricultural sector, technology and labour employed in the sector. Manufacturing output is assumed to be represented by a Cobb-Douglas type, determined by credit to the manufacturing sector, price, exchange rate, technology and labour employed in the manufacturing sector. Oil output and price per barrel of crude are exogenously determined. In the fiscal block, the researchers specify two equations, the government revenue and expenditure equations, and the block is closed with an identity.

The aggregate demand block includes equations for consumption and investment demand. In the labour market block, demand for and supply of labour unemployment equations are specified and the block is closed with an identity showing equilibrium in the labour market.

In the external block, the researchers specify the exchange rate equation, and the import and export equations. The import equations are disaggregated into capital and consumer goods imports. Exports are also disaggregated into agricultural and manufacturing exports. The equations are presented in Appendix IV.

\subsection{Methodological issues}

One of the objectives of this study is to investigate the dynamics in the interaction of monetary variables with various sub-sectors of the Nigerian economy. To do this, the researchers explored the co-integration theory/ error correction mechanism. Given data instability in Nigeria occasioned by, inter alia, policy instability and political or economic disruptions, it becomes increasingly useful to test the time series property of the variables for meaningful economic results. It is clear that OLS regression estimates with non-stationary time series data often produce unacceptable results, even though the overall results may indicate a high degree of fit as measured by coefficient of multiple correlation, or adjusted coefficient $\left(\mathrm{R}^{2}\right)$, high auto correlated residuals and statistical significance as measured by DW and the usual t-statistics respectively (Gujarati, 2004: 822-824). Moreover, many economic variables have a strong tendency to trend over time, so that the levels of these variables can be characterised as non-stationary, since they do not have a constant mean over time. Yet many analyses of unadjusted non-stationary series have been carried out on the assumption that such series are of no significance. Difficulties may arise in carrying out regression with clearly non-stationary series, leading to the so-called "spurious" regression (Granger \& Newbold, 1974: 115). Given two completely unrelated but integrated series, regression of one on the other will tend to produce an apparently significant relationship when, in fact, they are not related.

This study therefore adopts the co-integration/ error correction methodology to estimate eighteen stochastic equations listed in the appendix. This selection is based on the premise that if the variables were non-stationary, the desirable properties of consistency, efficiency, and absence of bias would be lost if the Ordinary Least Squares (OLS) technique was used to estimate the equations, which could lead to spurious results and inference, hence, inaccurate predictions. Co-integration and error correction are used to add richness, flexibility and versatility to the econometric modelling and to integrate short-run dynamics with long-run equilibrium. Hence accurate predictions can be more confidently made on the economic relationship between the variables.

The researchers also conducted a set of simulation experiments using the estimated 
version of the model. The major objective of the simulation exercise was to derive an appropriate set of policy to achieve specific improvement in key macroeconomic aggregates. There are basically two types of simulation: historical simulation and policy simulation. Historical simulation allows for the validation, evaluation of, and counter-factual analysis of the model. The importance of the historical stimulation is clear and straightforward. It enables the model builder to compare the simulated and the actual series in order to determine how well the macro-econometric model tracks the economy (Iyoha, 2002: 175). If the simulated values for all or most endogenous variables are very close to the actual values, then one is forced to conclude that the econometric model suitably describes the structure of the Nigerian economy. The paper uses the root-mean-squared error (rmse), root-mean-squared per cent error (rmpe), Theil's inequality coefficient and the correlation coefficient between the actual and simulated values of key endogenous variables to evaluate the performance of the model. The dynamic simulation for this work is undertaken for the period 1970-2004.

The purpose of policy simulation is to enable the researcher to predict the response of key endogenous variables to changes in identified policy instruments like government expenditure and money supply. As Iyoha (2002) pointed out, predicting policy responses is more or less indispensable for effective macroeconomic management and policy analysis.

\section{4}

\section{Empirical results and discussions}

\subsection{Testing for unit roots}

To test for the level of integration used in the model, the researchers employed the wellknown augmented Dickey-Fuller and PhilipPeron tests. The purpose was to determine whether the variables followed a non-stationary trend, and were, in fact, of the order of one denoted by 1(1) or whether the series were stationary, that is of the order 1(0). If the series were not stationary, the use of classical methods of estimation like OLS could lead to unwitting acceptance of a meaningless result. Moreover, in cases where the series are non-stationary around their mean, the traditional practice is to obtain the first difference of the series. In most cases this leads to stationarity, allowing the researcher to apply conventional econometrics (Granger $\&$ Newbold, 1974). The major disadvantage of first differencing is that it prevents the detection of a long-run relationship that may be present in the data. In other words, the vital long-run information is lost, which is one of the major questions being addressed.

Table IV.1 presents the results of the unit root test based on the ADF and PP tests. The results obtained provide strong evidence that the majority of the time series variables were stationary at first difference, while others were stationary at levels. This means that the majority of the variables of interest were integrated of order 1, which is 1(1) at 95 per cent confidence interval level. The result indicated that the null hypothesis could not be rejected for some of the variables under scrutiny. Since some of the series were 1(1) and others were 1(0), based on the Philip Peron test, the use of classical estimation techniques like OLS and others, like t-tests and F-tests, could lead to mistaken or false acceptance of spurious relationship among the variables. Since some of the variables were non-stationary at levels and others were integrated of order one, it was possible to conclude that various sub-sets of the variables under consideration may be integrated. Further analysis would obviously be required to test this conjecture.

The next task was to investigate whether the series under consideration was co-integrated, so that a well-defined relationship existed between them in the long run. To do this, the researchers adopted the Engle-Granger Two Step procedure and the error correction paradigms. The EngleGranger Two Step procedure is simple and straightforward. It involves running regression using stationary time series achieved by using first difference of the variables and including the lagged residuals from the levels regression in the regression as an explanatory variable. The results of the Engle-Granger tests for the eighteen stochastic equations, which were not reported because of lack of space, indicate that 
the residuals followed a $\mathrm{I}(0)$ process using an ADF and a PP test and had the correct signs, showing that the residuals from the levels regression were well defined, indicating strong evidence of the existence of a linear relationship between dependent and explanatory variables included in the regressions (Gujarati, 2004).

The presence of co-integration made it possible to estimate the error correction mechanism (ECM), which is a solution to the problem of spurious results associated with estimating equations involving time series variables, and to capture dynamic adjustment to the long run (Patterson, 1990: 335). Adopting the general to specific framework, the researchers proceeded to estimate the over-parametised error correction model of the eighteen stochastic equations from where parsimonious (preferred) error correction models were obtained. The novelty of ECM is that it provides a framework to establish the links between the long- and short-run approaches to economic modelling, which allows the researcher to test for the significance of the variables both in levels and in difference forms. Thus, with ECM, no information associated with the variable first differencing is lost, because the modelling technique incorporates both the short-run dynamics and long-run information through the error correction term. The over-parametised error correction models of the eighteen equations are not presented owing to lack of space. The equations include the ECM term lagged one period, representing the past value of the error correction factor, whose coefficient should be negative and statistically significant to support the existence of co-integration.

The over-parametised model was further estimated using the general to specific approach and the summary of the parsimonious (preferred) model is presented in Tables IV.2 to IV.7. The parsimonious model is arrived at by eliminating the jointly insignificant variables. A careful examination of the parsimonious results shows that the error correction term is well specified, as it has the expected a priori sign (negative), and is statistically different from zero. The significance of the error term suggests that the variables are co-integrated. To confirm this inference, the researchers checked the ADF and PP tests from all the residuals of the regressions; the ADF and PP tests were all significant at the 1 per cent level, showing strongly that the variables are co-integrated.

The quantitative result based on the parsimonious model shows that the money-supply process in Nigeria is explained by fiscal deficit and one year lagged money supply. The inflation equation agrees with the maintained hypothesis that inflation in Nigeria is caused by excessive money supply, exchange rate depreciation and the opening up of the economy to foreign competition. In the demand for currency outside banks, savings deposits and time deposit equations, the results show that GDP, interest rates and inflation are the significant factors that influenced them. In the fiscal block, the banking system credit to government; level of productivity (proxied by real GDP); one year lagged government revenue and expenditure are all significant variables affecting government expenditure and revenue. In the demand block, monetary variables such as interest rates; disposable income and one year lagged GDI are the significant variables influencing consumption and investment behaviour of households and firms. Monetary variables also enter the aggregate supply block via credit to manufacturing and agricultural sectors as well as the cost of capital. These monetary variables were found to conform to a priori expectation and were statistically significant.

The increase in the banking system's credit to the production block, which results in increased productivity, enters the labour market through increased labour demand. This is because GDP, which is a proxy for the level of economic activity, conforms to a priori economic expectations and is statistically significant in the unemployment equation. This suggests that increases in economic activities translate into more employment. In the external sector, monetary variables enter through the exchange rate, money supply and interest rate channels. Thus, overall monetary variables interact with various sub-sectors of the Nigerian economy through money supply, the exchange rate and credit channels.

Further, to find out how well the model tracked the actual data series historical simulation was 
carried out. The results of the simulation exercise were evaluated by making use of the simulation error statistics (the result is reported in Tables IV.8 and IV.9 in the Appendix). The evaluation of the model shows that the predictive performance of the model was adequate. The need to evaluate a model through the use of correlation coefficient, Root-Mean Squared Error, Mean Error and Theil's inequality coefficient was demonstrated and reported in Table IV.9.

The simulation result reveals that more money supply means higher output and employment, as well as a higher price level. If the growth in money supply were maintained at 5 per cent, this would reduce inflation and manufacturing output by about 2.11 and 0.41 percentage points respectively. In the external sector, a 5 per cent growth rate in money supply would reduce raw materials imports and capital goods imports by 0.15 and 0.84 percentage points respectively. A growth rate of money supply of 5 per cent would boost domestic consumption by about 12.84 per cent. The simulation result also reveals that reducing money supply by 20 per cent would lead to a drop in inflation faster than if money supply were reduced by 10 per cent.

\section{5 \\ Policy recommendations and conclusion}

The study has examined the mechanics by means of which monetary variables interact with fiscal and real variables, as well as external sector variables. The result shows that growth rate in money supply is fuelled by large fiscal deficits and that fiscal discipline should be practised by keeping to budgetary provisions. The result of the inflation equation based on the preferred or parsimonious model reveals that inflation in Nigeria is caused by both domestic and external factors. Domestic factors are brought about by excessive growth in money supply and, on the external front, greater opening up of the domestic economy to foreign competition. This means that there is an urgent need to boost domestic production. It follows that the current policy of an outright ban on the importation of certain commodities that could be produced locally should be sustained.

In the production block it was clear that credit to that sector, the interest rate and technology were significant factors influencing the growth rate of output. This means that the current consolidation of banks should be sustained. To promote output, the government should encourage technological advancement, involving both invention (the discovery and development of new products or new production techniques) and innovation (the practical or commercial application of such discoveries and techniques in the production of goods).

The banking system plays a crucial role in the transmission of monetary policy via its credit to the agricultural sector, manufacturing sector and government. Therefore the current reform agenda in the banking system as well as the NEEDS (National Economic and Empowerment Strategy) requirement of fiscal discipline should be sustained, not only to sustain the growth in urgently-needed output but also to sustain higher growth with tolerable inflation.

There are other alternative policy scenarios that could be explored to shed more light on the effectiveness of monetary policy. To this end, the researchers suggest the use of the exchange rate and bank credit as an alternative policy simulation experiment in future studies of this nature.

\subsection{Conclusion}

The general conclusion suggested by the findings of this study is that a tight monetary policy designed to achieve a stable inflation and exchange rate is likely to have significant and undesirable effects on output and employment. The simulation result shows that a 10 per cent decrease in money supply leads to a reduction in the inflation rate by a 2.17 percentage point, while output and labour demand reduce by 0.41 and 0.35 percentage points respectively. This drop in output and labour demand as a result of the monetary squeeze may well impose a heavy burden in a developing country like Nigeria, because incomes are already near the subsistence level and the employment effect is likely to fall disproportionately on the nascent 
industrial sector. In conclusion, the study shows that there is a trade-off between higher GDP growth and inflation in Nigeria

\section{References}

AJAYI, SI (1978) "The demand for money in Nigeria: Comments and extensions", Nigerian Journal of Economic and Social Studies, 16, (1): 11-22. BODKIN, RG; KLEIN, LR \& MARWAH, K (1986b)

"Keynes and the origins of macro econometric modelling", Eastern Economic Journal, 11 (1): 442 -450 .

BOGUNJOKO, JO (1997) "Monetary dimension of the Nigerian economic crisis: Empirical evidence from a co-integration paradigm", The Nigerian Journal of Economic and Social Studies, 39 (2): 140-147. GUJARATI, DN (2004) Basic Econometric, Tata McGraw-Hill publishing Company, India, 817-830. GRANGER, CWJ \& NEWBOLD, P (1974) “Spurious regression in econometrics", Journal of Econometrics, 2(1): 111-20.

IKHIDE, SI (1998) "Simulating an econometric model of Nigeria's financial sector", The Nigerian Journal of Economic and Social Studies, 30: 1-25.

IYOHA, MA (1996) "Macro econometric models", In M. I. Obadan \& M.A. Iyoha (eds.) Macro Econometric Policy and Analysis: Tools and Techniques with Application to Nigeria, Ibadan: National Centre for Economic Management and Administration. IYOHA, MA (2002) "An econometric model of the Nigerian economy”, In Milton A Iyoha \& Chris O Itsede (eds.) The Nigerian Economy: Structure, Growth and Development, Ibadan: Mindex Publishers. JHINGAN, ML (1997) Monetary Economics, New Delhi:Vrinda Publications.
KHAN, MS \& MALCOLM DK (1981) "Stabilization programs in developing countries: A formal framework", IMF Staff Papers, 23: 1-53. MEYER, LH (2001) "Does money matter"? Federal Reserve Bank of St. Louis Monthly Review, September 82, 102-115.

NDEBBIO, JEU \& EKPO, A (1991) The Nigerian Economy at the Cross Roads: Policies and their Effectiveness, Calabar: University of Calabar Press. OJO, O (1973) "A medium-term planning model of the Nigerian economy", Nigerian Journal of Economic and Social Studies, 15: 80-96.

OLOFIN, S \& POLOAMINA, D (1984) The Revised CEAR - MAC IV Macro-econometric Model of the Nigerian Economy, Ibadan: Centre for Economic and Allied Research.

PALANIVEL, T \& KLEIN, R (1999) "An econometric model for India with emphasis on the monetary sector", The Development Economics, 37 (3) 275 - 336. PATTERSON, K (1990) An Introduction to Applied Econometrics: A Time Series Approach, United Kingdom: Palgrave Publishers.

SOLUDO, CC (1998) Macro Economic Policy Modelling of African Economics, Enugu: Acena Publishers.

TOBIN, J (1999) "Monetary policy: Recent theory and practice”, Cowles Foundation Papers, 97(5): 1-7.

UWUJAREN, GP (1977) "Specification and estimation of an economy-wide macro economic model for Nigeria", Nigeria Journal of Economic and Social Studies, 19: 107-134.

VALADKHANI, A (2003) "History of macro econometric modelling: Lessons from past experience", Papers on Economics, Finance and International Competitiveness presented at the School of Economics and Finance, Queensland University of Technology, Australia. 


\section{Appendix 1}

\section{Table 1}

Some selected macroeconomic indicators, 1970-2004

\begin{tabular}{|c|c|c|c|c|c|c|c|}
\hline $\begin{array}{l}\text { Obser- } \\
\text { vation }\end{array}$ & $\begin{array}{l}\text { Real gdp } \\
\text { growth } \\
\text { rate (\%) }\end{array}$ & $\begin{array}{c}\text { Money } \\
\text { supply(m2) } \\
\text { growth } \\
\text { rate }(\%)\end{array}$ & $\begin{array}{l}\text { Balance of } \\
\text { payments }\end{array}$ & Inflation & $\begin{array}{c}\text { Exchange } \\
\text { rate }\end{array}$ & $\begin{array}{c}\text { Overall } \\
\text { fiscal } \\
\text { balance }\end{array}$ & $\begin{array}{c}\text { Fiscal } \\
\text { balance as } \\
\% \text { of gdp }\end{array}$ \\
\hline 1970 & & & 46.2 & 13.8 & 0.7143 & -455.1 & -8.7 \\
\hline 1971 & 21.3 & 8 & 117.4 & 15.6 & 0.6955 & 171.6 & 2.6 \\
\hline 1972 & 5.48 & 11.96 & 57.2 & 3.2 & 0.6579 & -58.8 & -0.8 \\
\hline 1973 & 6.42 & 7.93 & 1927.5 & 5.4 & 0.6579 & 166.1 & 1.5 \\
\hline 1974 & 11.74 & 67.08 & 3102.2 & 13.4 & 0.6299 & 1796.4 & 9.8 \\
\hline 1975 & -2.96 & 15.81 & 157 & 33.9 & 0.6159 & -427.9 & -2 \\
\hline 1976 & 11.08 & 14.39 & -339 & 21.2 & 0.6265 & -1090.8 & -4 \\
\hline 1977 & 8.15 & 16.29 & -527.2 & 15.4 & 0.6466 & -781.4 & -2.4 \\
\hline 1978 & -7.37 & 15.92 & 1293.6 & 16.6 & 0.606 & -2821.9 & -7.8 \\
\hline 1979 & 2.44 & 17.35 & 1860.9 & 11.8 & 0.5957 & 1461.7 & 3.4 \\
\hline 1980 & 5.48 & 32.98 & 2402.2 & 9.9 & 0.5464 & -1975.2 & 3.9 \\
\hline 1981 & -26.8 & 12.51 & -3020.8 & 20.9 & 0.61 & -3902.1 & -7.7 \\
\hline 1982 & 0.34 & 1.79 & -1308.3 & 7.7 & 0.6729 & -6104.1 & -11.8 \\
\hline 1983 & -5.37 & 7.48 & -301.3 & 23.2 & 0.7241 & -3364.5 & -5.6 \\
\hline 1984 & -5.09 & 20.06 & 354.9 & 39.6 & 0.7649 & -2660.4 & -4.2 \\
\hline 1985 & 9.38 & 3.32 & 349.1 & 5.5 & 0.8938 & -3039.7 & -4.2 \\
\hline 1986 & 3.13 & 3.27 & -784.3 & 5.4 & 2.02575 & -8254.3 & -11.3 \\
\hline 1987 & 0.47 & 11.13 & 159.2 & 10.2 & 4.017942 & -5889.7 & -5.4 \\
\hline 1988 & 9.91 & 14.84 & -2294.1 & 38.2 & 4.536733 & -12160.9 & -8.4 \\
\hline 1989 & 7.39 & 24.96 & 8727.8 & 40.9 & 7.391558 & -15135 & -6.7 \\
\hline 1990 & 8.2 & 23.42 & 18490.2 & 7.5 & 8.037808 & -22116 & -8.5 \\
\hline 1991 & 4.73 & 21.73 & 5659.6 & 13 & 9.909492 & -35755 & -11 \\
\hline 1992 & 2.98 & 11.49 & -85271 & 44.5 & 17.29843 & -39533 & -7.2 \\
\hline 1993 & 2.65 & 97.1 & 13615 & 57.2 & 22.05106 & -107735 & -15.5 \\
\hline 1994 & 1.31 & 13.47 & -42623.3 & 57 & 21.8861 & -70271 & -7.7 \\
\hline 1995 & 2.15 & 30.9 & -195216 & 72.8 & 84.575 & 1000 & 0.1 \\
\hline 1996 & 3.39 & 10.26 & -53152 & 29.3 & 79.6 & 32049 & 1.6 \\
\hline 1997 & 3.16 & 8.07 & 1077.7 & 8.5 & 74.625 & -5000 & -0.2 \\
\hline 1998 & 2.31 & 11.73 & -224676 & 10 & 84.3679 & -133389 & -4.7 \\
\hline 1999 & 3.05 & 18 & -326634 & 6.6 & 96.1 & -285105 & -8.4 \\
\hline 2000 & 3.8 & 48.1 & -314128 & 6.9 & 101.7 & 103777 & -2.7 \\
\hline 2001 & 3.91 & 27 & 24728.8 & 18.9 & 111.901 & 221049 & -4 \\
\hline 2002 & 3.5 & 21.6 & -565353.3 & 13.2 & 120.9521 & 547000 & -5.5 \\
\hline 2003 & 10.2 & 24.1 & 162839.66 & 14 & 129.3612 & 662000 & -2.8 \\
\hline 2004 & 6.1 & 14.0 & 1128383.4 & 10.0 & 133.5 & 672500 & 13.7 \\
\hline
\end{tabular}

Note: Balance of payments and overall fiscal balance is in (\# million), the exchange rate is average rates, expressed in Naira per unit of the US Dollar.

Source: CBN Statistical Bulletin (various issues) 
Figure 1

Growth rate of money supply and GDP

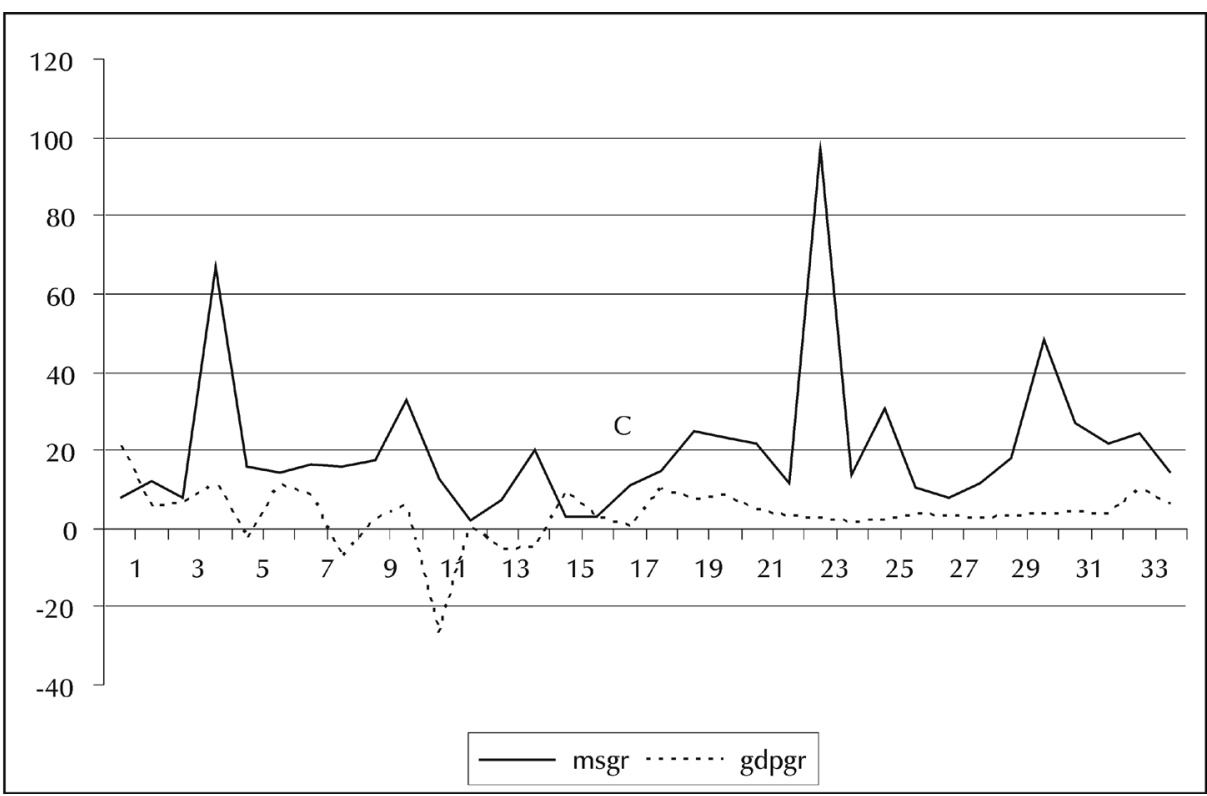

Figure 2

Growth rate of money supply and inflation

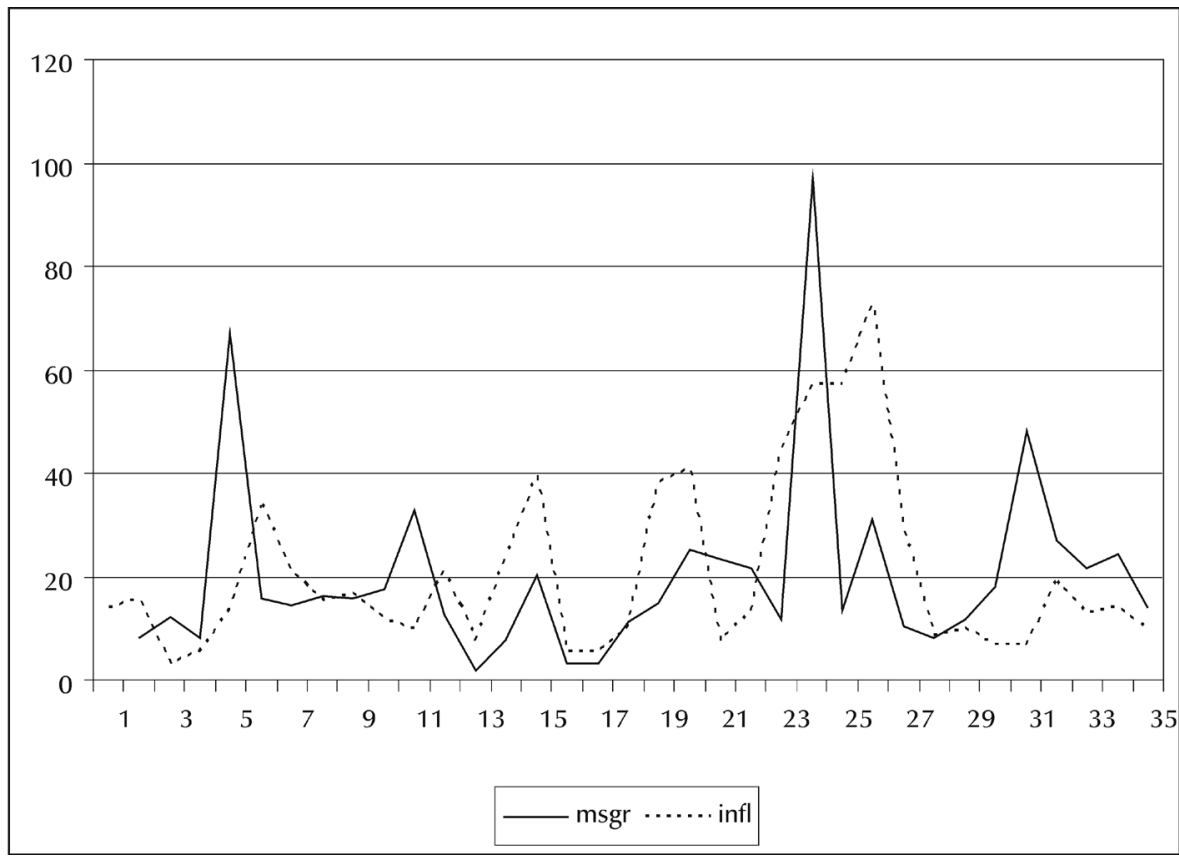




\section{Appendix 2}

\begin{tabular}{|c|c|c|c|c|c|c|c|}
\hline & & & $\begin{array}{r}\text { Tal } \\
\text { ults of } u\end{array}$ & $\begin{array}{l}\text { le } 2 \\
\text { nit root tests }\end{array}$ & & & \\
\hline Augmente & Dickey-Full & Test & & & & Phillip & Peron Test \\
\hline Variables & Levels & $1^{\text {st }}$ diff. & $\begin{array}{c}\text { Lag } \\
\text { length }\end{array}$ & $\begin{array}{l}\text { Order of } \\
\text { integration }\end{array}$ & Levels & $1^{\text {st }}$ diff. & $\begin{array}{c}\text { Order of } \\
\text { integration }\end{array}$ \\
\hline Cons & -4.107324 & & 2 & $\mathrm{I}(0)$ & -2.152683 & -4.244788 & $\mathrm{I}(1)$ \\
\hline $\mathrm{CPI}$ & -2.276662 & -3.713252 & 2 & $\mathrm{I}(1)$ & -2.53427 & -6.068631 & $\mathrm{I}(1)$ \\
\hline Creag & -2.521515 & -3.730026 & 2 & $\mathrm{I}(1)$ & -2.99135 & -3.836409 & $\mathrm{I}(1)$ \\
\hline Cregov & 0.116584 & -9.709685 & 2 & $\mathrm{I}(1)$ & -1.64523 & -4.731998 & $\mathrm{I}(1)$ \\
\hline Crexmn & $-5.970345^{*}$ & & 2 & $\mathrm{I}(0)$ & -6.681337 & & $\mathrm{I}(0)$ \\
\hline $\mathrm{Dd}$ & -2.280164 & -3.393856 & 2 & $\mathrm{I}(1)$ & -1.559959 & -3.587783 & $\mathrm{I}(1)$ \\
\hline Dsd & -2.518789 & -5.185271 & 2 & $\mathrm{I}(1)$ & -1.631559 & -4.329016 & $\mathrm{I}(1)$ \\
\hline Dtd & -5.31278 & & 2 & $\mathrm{I}(0)$ & -1.36487 & -2.712845 & $\mathrm{I}(1)$ \\
\hline Exchr & -1.160058 & -6.097316 & 2 & $\mathrm{I}(1)$ & -1.450564 & -6.088884 & $\mathrm{I}(1)$ \\
\hline GDI & -3.718510 & & 2 & $\mathrm{I}(0)$ & -3.462299 & & $\mathrm{I}(0)$ \\
\hline GDP & 0.750778 & -9.147459 & 2 & $\mathrm{I}(1)$ & 0.978103 & -5.6371128 & $\mathrm{I}(1)$ \\
\hline Gexp & -5.267930 & & 2 & $\mathrm{I}(0)$ & -3.86045 & & $\mathrm{I}(0)$ \\
\hline Grev & -7.784526 & & 2 & $\mathrm{I}(0)$ & -11.30994 & & $\mathrm{I}(0)$ \\
\hline Infla & -2.006639 & -5.593545 & 2 & $\mathrm{I}(1)$ & -2.500702 & -8.683967 & $\mathrm{I}(0)$ \\
\hline Ld & -2.606639 & -6.531587 & 2 & $\mathrm{I}(1)$ & -2.263282 & -10.90714 & $\mathrm{I}(1)$ \\
\hline Ls & -2.210895 & -5.692603 & 2 & $\mathrm{I}(1)$ & -2.227747 & -6.004872 & $\mathrm{I}(1)$ \\
\hline Ma & 0.754039 & -6.769000 & 2 & $\mathrm{I}(1)$ & -2.267486 & -12.81969 & $\mathrm{I}(1)$ \\
\hline $\mathrm{Mb}$ & -3.191992 & & 2 & $\mathrm{I}(0)$ & -4.571471 & & $\mathrm{I}(0)$ \\
\hline Ms & -1.376792 & -6.284538 & 2 & $\mathrm{I}(1)$ & -2.56328 & -11.47846 & $\mathrm{I}(1)$ \\
\hline Pop & 0.6755051 & -5.926327 & 2 & $\mathrm{I}(1)$ & 1.507996 & -5.966326 & $\mathrm{I}(1)$ \\
\hline $\mathrm{R}$ & -1.800722 & -2.767227 & 2 & $\mathrm{I}(1)$ & -1.691238 & -7.044380 & $\mathrm{I}(1)$ \\
\hline Unempl & -1.176402 & -5.584556 & 2 & $\mathrm{I}(1)$ & -1.166338 & -5.583252 & $\mathrm{I}(1)$ \\
\hline Xa & 0.905367 & -2.641272 & 2 & $\mathrm{I}(1)$ & 0.428697 & -3.685680 & $\mathrm{I}(1)$ \\
\hline $\mathrm{Xb}$ & -5.885273 & & 2 & $\mathrm{I}(0)$ & -5.885408 & & $\mathrm{I}(0)$ \\
\hline Xag & -1.642501 & -4.329120 & 2 & $\mathrm{I}(1)$ & -1.240660 & -4.299298 & $\mathrm{I}(1)$ \\
\hline $\mathrm{Xmn}$ & -1.741366 & -4.956209 & 2 & $\mathrm{I}(1)$ & -1.735757 & -4.963810 & $\mathrm{I}(1)$ \\
\hline Yd & -4.818745 & & 2 & $\mathrm{I}(0)$ & -2.173194 & -5.596820 & $\mathrm{I}(1)$ \\
\hline Fdef & -3.887832 & & 2 & $\mathrm{I}(0)$ & -3.720615 & & $\mathrm{I}(0)$ \\
\hline $\mathrm{Rw}$ & -1.832747 & -4.347639 & 2 & $\mathrm{I}(1)$ & -1.938254 & -4.347639 & $\mathrm{I}(1)$ \\
\hline
\end{tabular}

Critical Values at

$1 \%=-3.653701 \%=-3.646342$

$5 \%=-2.9571105 \%=-2.954021$

$10 \%=-2.61743410 \%=-2.615817$ 


\section{Appendix 3}

\section{The parsimonious error correction model}

\section{Table 3}

Monetary block equations

\begin{tabular}{|c|c|c|c|c|c|}
\hline Equations & 2 & 3 & 4 & 6 & 7 \\
\hline $\begin{array}{l}\text { Dependent } \\
\text { variables }\end{array}$ & $\begin{array}{l}D \log (\mathrm{Dd}) \\
0.149179 \\
(2.38009)\end{array}$ & $\begin{array}{c}\text { Dlog(Dsd) } \\
0.199605 \\
(3.96387)\end{array}$ & $\begin{array}{c}\log (\mathrm{Dtd}) \\
0.236334 \\
(8.961029)\end{array}$ & $\begin{array}{c}\text { Dlog(Ms) } \\
0.027106 \\
(7.942872)\end{array}$ & $\begin{array}{c}\text { Infla } \\
4.184283 \\
(10.89422)\end{array}$ \\
\hline Dlog(GDP) & $\begin{array}{c}0.738463 \\
(2.047442)\end{array}$ & $\begin{array}{c}0.524895 \\
(1.637298)\end{array}$ & $\begin{array}{c}0.160809 \\
(1.789610)\end{array}$ & & $\begin{array}{l}-0.931392 \\
(-1.61072)\end{array}$ \\
\hline D(Inlfa) & $\begin{array}{l}-0.801605 \\
(1.741792)\end{array}$ & $\begin{array}{c}0.140210 \\
(1.814517)\end{array}$ & $\begin{array}{c}-0.007612 \\
(0.808431)\end{array}$ & & \\
\hline$d R$ & $\begin{array}{c}0.356102 \\
(1.838592)\end{array}$ & $\begin{array}{c}-0.018842 \\
(1.527071)\end{array}$ & $\begin{array}{l}-0.008629 \\
(2.327718)\end{array}$ & & \\
\hline Fdef & & & & $\begin{array}{c}0.350123 \\
(1.723460)\end{array}$ & \\
\hline Dlog(Exchr) & & & & & $\begin{array}{c}0.010679 \\
(2.585905\end{array}$ \\
\hline Dlog(ms) & & & & & $\begin{array}{c}0.580502 \\
(2.427395)\end{array}$ \\
\hline Open & & & & & $\begin{array}{c}0.161850 \\
(8.506414)\end{array}$ \\
\hline $\log \left(M s_{t-1}\right)$ & & & & $\begin{array}{c}0.068979 \\
(1.632943)\end{array}$ & \\
\hline $\mathrm{Ecm}_{\mathrm{t}-1}$ & $\begin{array}{l}-0.096153 \\
(3.422601)\end{array}$ & $\begin{array}{l}-0.105571 \\
(3.532096)\end{array}$ & $\begin{array}{c}-0.984135 \\
(4.35508)\end{array}$ & $\begin{array}{l}-0.078912 \\
(1.736763)\end{array}$ & $\begin{array}{l}-1.276798 \\
(1.625028)\end{array}$ \\
\hline $\mathrm{R}^{2}$ & 0.37 & 0.36 & 0.97 & 0.87 & 0.65 \\
\hline DW & 1.56 & 1.76 & 1.67 & 1.57 & 1.79 \\
\hline
\end{tabular}

* Values in parenthesis are the t-statistics 
Table 4

Government block equations

\begin{tabular}{|c|c|c|}
\hline Equations & 10 & 11 \\
\hline Dependent variable & $\begin{array}{c}\log (G \exp ) \\
0.037798 \\
(0.174146)\end{array}$ & $\begin{array}{c}\log (\text { Grev }) \\
0.302835 \\
(0.956064)\end{array}$ \\
\hline Dlog(GDP) & $\begin{array}{c}0.911824 \\
(3.434676)\end{array}$ & $\begin{array}{c}1.072377 \\
(1.498235)\end{array}$ \\
\hline Dlog(pop) & $\begin{array}{c}1.099199 \\
(1.742280)\end{array}$ & \\
\hline Dlog(cregov) & $\begin{array}{c}0.035763 \\
(1.645969)\end{array}$ & \\
\hline $\log \left(G \exp _{t-1}\right)$ & $\begin{array}{c}1.009545 \\
(51.56284)\end{array}$ & \\
\hline Dlog(Exchr) & & $\begin{array}{c}0.011928 \\
(2.086662)\end{array}$ \\
\hline $\log \left(\operatorname{Grev}_{\mathrm{t}-1}\right)$ & & $\begin{array}{c}0.988462 \\
(33.56565)\end{array}$ \\
\hline $\mathrm{ecm}_{\mathrm{t}-1}$ & $\begin{array}{l}-0.514905 \\
(3.332408)\end{array}$ & $\begin{array}{l}-0.075243 \\
(1.609401)\end{array}$ \\
\hline$R^{2}$ & 0.99 & 0.98 \\
\hline DW & 2.02 & 2.33 \\
\hline
\end{tabular}

* Values in parenthesis are the t-statistics

Table 5

Aggregate demand equations

\begin{tabular}{|l|c|c|}
\hline \multicolumn{1}{|c|}{ Equations } & $\mathbf{1 3}$ & $\mathbf{1 4}$ \\
\hline Dependent variables & Con & GDI \\
& 0.076487 & 0.93578 \\
& $(0.115343)$ & $(0.309980)$ \\
\hline $\log (\mathrm{Yd})_{\mathrm{t}-1}$ & 0.396071 & \\
\hline $\mathrm{DR}$ & $(2.616071)$ & \\
\hline $\operatorname{Dlog}(\mathrm{GDP})$ & -0.035178 & -0.037819 \\
& $(1.783932)$ & $(1.734523)$ \\
\hline $\log (\mathrm{GDI}) \mathrm{t}-1$ & & 1.451281 \\
& & $(0.723504)$ \\
\hline Ecm & & 0.802632 \\
$\mathrm{t}-1$ & & $(1.851002)$ \\
\hline $\mathrm{R}^{2}$ & -0.145297 & -0.583418 \\
\hline $\mathrm{DW}$ & $(1.600102)$ & $(1.680508)$ \\
\hline
\end{tabular}

*Values in parenthesis are the t-statistics 


\section{Table 6}

Production block equations

\begin{tabular}{|l|c|c|}
\hline \multicolumn{1}{|c|}{ Equations } & $\mathbf{1 6}$ & $\mathbf{1 7}$ \\
\hline Dependent variables & Dlog(Xag) & Dlog(Xmn) \\
& 0.145786 & 0.266154 \\
& $(1.583098)$ & $(3.440782)$ \\
\hline Dlog(creag) & 0.132410 & \\
\hline DR & $(1.675360)$ & -0.014052 \\
& -0.011309 & $(1.786544)$ \\
\hline Log(tech) & $(2.137002)$ & 0.064161 \\
& 0.066192 & $2.393393)$ \\
\hline Dlog(pop) & $(2.244840)$ & 0.463749 \\
& 0.952540 & $(1.989653)$ \\
\hline Dlog(crexmn) & $(2.433232)$ & 0.025670 \\
& & $(1.633458)$ \\
\hline Ecm ${ }_{\mathrm{t}-1}$ & & -0.329366 \\
& & $(-2.608034)$ \\
\hline $\mathrm{R}^{2}$ & -0.320329 & 0.26 \\
\hline DW & $(2.865235)$ & 1.69 \\
\hline
\end{tabular}

* Values in parenthesis are the t-statistics

Table 7

Labour market equations

\begin{tabular}{|c|c|c|c|}
\hline Equations & 20 & 21 & 22 \\
\hline Dependent variable & $\begin{array}{c}\mathrm{D} \log (\mathrm{Id}) \\
0.041099 \\
(0.141595)\end{array}$ & $\begin{array}{c}\operatorname{Dlog}(\mathrm{ls}) \\
0.042019 \\
(0.524595)\end{array}$ & $\begin{array}{c}\text { Dlog(unempl) } \\
0.318135 \\
(0.086657)\end{array}$ \\
\hline $\operatorname{Dlog}(\mathrm{RW})$ & $\begin{array}{c}0.071695 \\
(1.586067)\end{array}$ & $\begin{array}{l}0.040595 \\
(1.78887)\end{array}$ & $\begin{array}{c}0.657112 \\
(0.313594)\end{array}$ \\
\hline Dlog(GDP) & $\begin{array}{l}0.022274 \\
(0.08607)\end{array}$ & $\begin{array}{c}0.031967 \\
(1.455530)\end{array}$ & $\begin{array}{c}0.551186 \\
(15.931801)\end{array}$ \\
\hline $\mathrm{ECm}_{\mathrm{t}-1}$ & $\begin{array}{l}-0.076300 \\
(1.523562)\end{array}$ & $\begin{array}{l}-0.127560 \\
(1.640864)\end{array}$ & $\begin{array}{l}-0.151622 \\
(1.677084)\end{array}$ \\
\hline $\mathrm{R}^{2}$ & 0.56 & 0.64 & 0.45 \\
\hline DW & 1.96 & 1.76 & 2.41 \\
\hline
\end{tabular}

* Values in parenthesis are the t-statistics 
Table 8

External sector equations

\begin{tabular}{|c|c|c|c|c|c|}
\hline Equations & 26 & 27 & 28 & 29 & 30 \\
\hline $\begin{array}{l}\text { Dependent } \\
\text { variable }\end{array}$ & $\begin{array}{c}\operatorname{Dlog}(\mathrm{Xa}) \\
0.179943 \\
(0.975465)\end{array}$ & $\begin{array}{c}\log (\mathrm{Xb}) \\
0.46662 \\
(0.034564)\end{array}$ & $\begin{array}{c}\text { Dlog(Mcap) } \\
0.42912 \\
(0.180849)\end{array}$ & $\begin{array}{c}\text { Log(Mcons) } \\
0.160591 \\
(0.883675)\end{array}$ & $\begin{array}{c}\text { Dlog(exchr) } \\
0.205395 \\
(2.041892)\end{array}$ \\
\hline Dlog(creag) & $\begin{array}{c}0.044750 \\
(1.621422)\end{array}$ & & & & \\
\hline Dlog(exchr) & $\begin{array}{l}-0.145047 \\
(1.717966)\end{array}$ & $\begin{array}{c}0.807211 \\
(1.601839)\end{array}$ & $\begin{array}{l}-0.050118 \\
(1.612275)\end{array}$ & $\begin{array}{l}-0.048600 \\
(1.713763)\end{array}$ & \\
\hline Dlog(GDP) & $\begin{array}{l}0.4243211 \\
(3.261996)\end{array}$ & $\begin{array}{c}0.261483 \\
(1.627551)\end{array}$ & & & $\begin{array}{c}0.544871 \\
1.663991)\end{array}$ \\
\hline Dlog(рор) & $\begin{array}{c}0.256732 \\
(1.701827)\end{array}$ & $\begin{array}{l}0.282514 \\
(3.76504)\end{array}$ & & & \\
\hline Log(crexmn) & & $\begin{array}{c}0.542341 \\
(2.205459)\end{array}$ & & & \\
\hline $\operatorname{Dlog}(m s)$ & & & $\begin{array}{c}0.070796 \\
(1.630967)\end{array}$ & $\begin{array}{c}0.302969 \\
(1.647600)\end{array}$ & $\begin{array}{c}0.278975 \\
(1.732571)\end{array}$ \\
\hline $\mathrm{D}(\mathrm{R})$ & & & $\begin{array}{l}-0.034249 \\
(1.692439)\end{array}$ & & \\
\hline $\mathrm{ecm}_{\mathrm{t}-1}$ & $\begin{array}{l}-0.797250 \\
(4.429133)\end{array}$ & $\begin{array}{l}-0.129190 \\
(5.969780)\end{array}$ & $\begin{array}{l}-0.028426 \\
(1.806004)\end{array}$ & $\begin{array}{l}-0.345642 \\
(1.671245)\end{array}$ & $\begin{array}{l}-0.091494 \\
(1.505874)\end{array}$ \\
\hline $\mathrm{R}^{2}$ & 0.42 & 0.56 & 0.67 & 0.58 & 0.34 \\
\hline DW & 1.80 & 1.76 & 1.86 & 1.98 & 1.71 \\
\hline
\end{tabular}

* Values in parenthesis are the t-statistics

Table 9

Summary of dynamic policy simulation based on monetary policy (cumulative) 1995-2004

\begin{tabular}{|c|l|c|c|c|}
\hline & & $\mathbf{5 \%}$ increase in $\mathbf{~ s}$ & $\mathbf{1 0} \mathbf{~ d e c r e a s e ~ i n ~} \mathbf{~ m s}$ & $\mathbf{2 0} \mathbf{0}$ decrease in ms \\
\hline 1 & Inflation & -0.211 & -2.176 & -2.76 \\
\hline 2 & Exchange rate & 3.67 & 3.58 & 4.04 \\
\hline 3 & Consumer imports & 0.0447 & 0.035 & 0.089 \\
\hline 4 & Raw materials imports & -0.15 & -0.15 & -0.74 \\
\hline 5 & Capital goods imports & -0.84 & -0.85 & -0.3116 \\
\hline 6 & Government expenditure & -0.32 & -0.32 & -0.24 \\
\hline 7 & Government revenue & -0.28 & - & 12.95 \\
\hline 8 & Consumption & 12.84 & 12.81 & 0.85 \\
\hline 9 & Gross domestic investment & 0.76 & 0.74 & 0.41 \\
\hline 10 & Agricultural output & 0.41 & 0.41 & \\
\hline
\end{tabular}




\begin{tabular}{|c|l|c|c|c|}
\hline 11 & Manufacturing output & -0.42 & -0.41 & -0.42 \\
\hline 12 & Demand for labour & -0.36 & -0.36 & -0.36 \\
\hline 13 & Labour supply & 1.11 & 1.12 & 1.04 \\
\hline 14 & Unemployment & 3.09 & 3.13 & 2.71 \\
\hline
\end{tabular}

Source: Compiled by author

Table 10

Historical simulation: Summary statistics

\begin{tabular}{|c|c|c|c|c|c|c|}
\hline & & $\begin{array}{l}\text { Correlation } \\
\text { coefficient }\end{array}$ & rmse & Mean error & \multicolumn{2}{|c|}{$\begin{array}{l}\text { Theil's inequality } \\
\text { coefficient }\end{array}$} \\
\hline & & & & & 1961 & 1966 \\
\hline 1 & Money supply & 0.76899 & 1.2684 & -5.7784 & 0.061446 & 0.12243 \\
\hline 2 & Inflation & 0.36837 & 16.73830 & 1.2643 & 0.32765 & 0.61380 \\
\hline 3 & Exchange rate & 0.95724 & 0.62821 & 4.96705 & 0.11272 & 0.22287 \\
\hline 4 & Consumer imports & 0.94991 & 0.82872 & 4.3348 & 0.0407 & 0.081544 \\
\hline 5 & Raw materials imports & 0.96522 & 0.68318 & -2.8899 & 0.034147 & 0.68251 \\
\hline 6 & Capital goods imports & 0.93681 & 0.85065 & 1.4449 & 0.040468 & 0.080800 \\
\hline 8 & Government expenditure & 0.98955 & 0.29800 & 4.33488 & 0.013571 & 0.027140 \\
\hline 9 & Government revenue & 0.89318 & 0.99215 & 4.33488 & 0.044930 & 0.089695 \\
\hline 10 & Consumption & 0.73679 & 1.81555 & 2.8899 & 0.075369 & 0.15025 \\
\hline 11 & Gross domestic investment & 0.38251 & 0.68274 & 2.88992 & 0.057099 & 0.11381 \\
\hline 12 & Agricultural output & 0.97341 & 0.16244 & -2.88992 & 0.0075634 & 0.015726 \\
\hline 13 & Manufacturing output & 0.96495 & 0.13986 & -7.2248 & 0.015710 & 0.031413 \\
\hline 15 & Demand for labour & 0.25377 & 0.66677 & 1.44496 & 0.036432 & 0.72766 \\
\hline 16 & Labour supply & 0.34607 & 0.87251 & -2.8892 & 0.038429 & 0.076773 \\
\hline 17 & Unemployment & 0.46853 & 19.15149 & -2.3119 & 0.23743 & 0.46078 \\
\hline
\end{tabular}

Source: Compiled by author 


\section{Appendix 4}

\section{Summary of equations:}

$$
\begin{aligned}
& \text { The monetary block } \\
& M^{d}=d D D+d S d+d T d \\
& d D D=X_{0}+X_{1} G D P+X_{2} I N F L A+X_{3} R+X_{4} d_{D D}+U t \\
& X_{2}<0 ; X_{1}, X_{3}, X_{4}>0 \\
& d S d=X_{0}+X_{1} R+X_{2} G D P+X_{3} I N F L A+X_{4} d S d_{-1}+U t \\
& X_{1}<0, X_{2}, X_{3}, X 4 \geq 0 \\
& d T D=X_{0}+X_{1} G D P+X_{2} I N F L A+X_{3} R+X_{4} d T D_{-1}+U t \\
& X_{2} X_{3}<0 ; X_{1} X_{4}>0
\end{aligned}
$$

\section{Government block:}

FDEF $=$ GEXP - GREV 


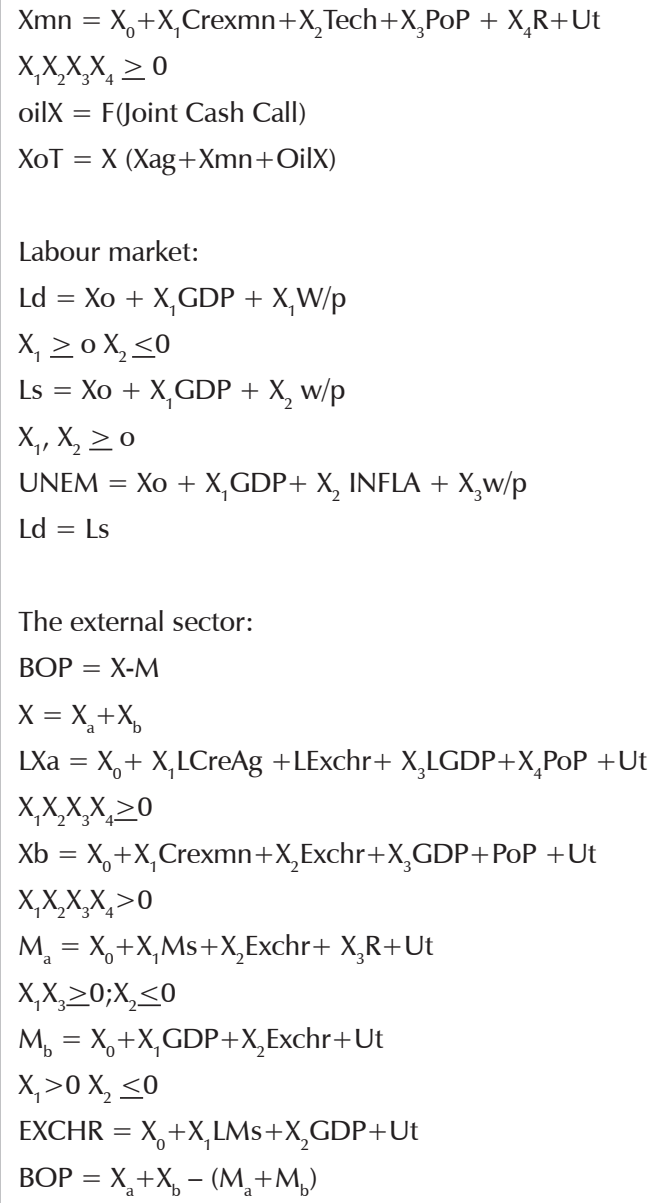

The external sector:

$\mathrm{BOP}=\mathrm{X}-\mathrm{M}$

$X=X_{a}+X_{b}$

$\mathrm{LXa}=\mathrm{X}_{0}+\mathrm{X}_{1} \mathrm{LCreAg}+\mathrm{LExchr}+\mathrm{X}_{3} \mathrm{LGDP}+\mathrm{X}_{4} \mathrm{PoP}+\mathrm{Ut}$

$\mathrm{X}_{1} \mathrm{X}_{2} \mathrm{X}_{3} \mathrm{X}_{4} \geq 0$

$\mathrm{Xb}=\mathrm{X}_{0}+\mathrm{X}_{1}$ Crexmn $+\mathrm{X}_{2}$ Exchr $+\mathrm{X}_{3}$ GDP $+\mathrm{PoP}+\mathrm{Ut}$

$\mathrm{X}_{1} \mathrm{X}_{2} \mathrm{X}_{3} \mathrm{X}_{4}>0$

$\mathrm{M}_{\mathrm{a}}=\mathrm{X}_{0}+\mathrm{X}_{1} \mathrm{Ms}+\mathrm{X}_{2}$ Exchr $+\mathrm{X}_{3} \mathrm{R}+\mathrm{Ut}$

$\mathrm{X}_{1} \mathrm{X}_{3} \geq 0 ; \mathrm{X}_{2} \leq 0$

$M_{b}=X_{0}+X_{1} G D P+X_{2}$ Exchr $+U t$

$\mathrm{X}_{1}>0 \mathrm{X}_{2} \leq 0$

$\mathrm{EXCHR}=\mathrm{X}_{0}+\mathrm{X}_{1} \mathrm{LMs}+\mathrm{X}_{2} \mathrm{GDP}+\mathrm{Ut}$

$\mathrm{BOP}=\mathrm{X}_{\mathrm{a}}+\mathrm{X}_{\mathrm{b}}-\left(\mathrm{M}_{\mathrm{a}}+\mathrm{M}_{\mathrm{b}}\right)$ 
Table 11

Definition of variables

\begin{tabular}{|c|c|c|}
\hline Code & Description of variables & Variable type \\
\hline $\mathrm{Dd}$ & Currency outside banks & Predetermine \\
\hline Dsd & Demand for saving deposit & Predetermine \\
\hline Dtd & Demand for time deposit & Predetermine \\
\hline Infla & inflation & Predetermine \\
\hline $\mathrm{Mb}$ & Monetary base & Predetermine \\
\hline Ms & Broad money supply & Exogenous \\
\hline Gexp & Government expenditure & Predetermine \\
\hline Grev & Government revenue & Predetermine \\
\hline Cons & Consumption & Predetermine \\
\hline Gdi & Gross domestic investment & Predetermine \\
\hline Xag & Agricultural output & Endogenous \\
\hline Xmn & Manufacturing output & Exogenous \\
\hline Cremn & Credit to manufacturing sector & Exogenous \\
\hline Creag & Credit to agric. sector & Exogenous \\
\hline Ld & Labour demand & Endogenous \\
\hline Ls & Labour supply & Endogenous \\
\hline Unempl & Unemployment & Endogenous \\
\hline Xa & Agricultural export & Endogenous \\
\hline $\mathrm{Xb}$ & Manufacturing export & Endogenous \\
\hline Ma & Capital goods export & Endogenous \\
\hline $\mathrm{Mb}$ & Consumer goods export & Endogenous \\
\hline Exchr & Exchange rate & Exogenous \\
\hline gdp & Gross domestic product & Exogenous \\
\hline рор & Population & Exogenous \\
\hline Cregov & Credit to government & Exogenous \\
\hline tech & Technology & Exogenous \\
\hline
\end{tabular}

